\title{
THE PHENOMENON OF PLAY IN THE CONTEXT OF THEATRICAL AND STAGE ART: TO THE PROBLEM OF UNDERSTANDING
}

\author{
Huang Shaobo \\ Applicant at the Department of Music History and Musical Ethnography, \\ Odessa National A.V. Nezdanova Academy of Music, Ukraine \\ e-mail: 515336178@qq.com,orcid.org/0000-0002-5131-9842
}

\section{Summary}

The article analyzes the main approaches to the study of the phenomenon of play, highlighting the key research positions on the way to identify the essence of this phenomenon. In most studies, the phenomenon of play is considered as a cultural universal and the main source of human cultural activity. In this regard, the main aim of this article is to consider the phenomenon of play as a necessary component of musical art, highlighting the importance of play logic in musical and stage genres. Consequently, the triad of the concepts of play - composition - motor ability, forms a single conceptual field, which contributes to the identification of the features of the ways of formation of music. Moreover, in this triad, it is the third component - motor ability - that appears as the first manifestation of the play purpose of the artistic form, which in turn is a manifestation of the inner drama and psychological subtext of the composition, which correlates it with stage and theatrical action, the phenomenon of theatricality, which acquires special relevance in musical art in general, and opera forms in particular.

Key words: play, play logic, actional and communicative nature of the play, theatricality, musical and stage genres.

DOI: https://doi.org/10.23856/4615

\section{Introduction}

The relevance of the chosen research direction is explained by the fact that the problem of play and the play basis of human activity can be considered as one of the most complex and requiring in-depth study, which can be confirmed by numerous references to this subject area by researchers of various specializations - psychologists, linguists, art historians, musicologists, culturologists. In the philosophical, psychological, aesthetic and art studies research traditions of the XIX-XX centuries, the problem of the play is considered on the pages of works by I. Kant, J. Huizinga, H. Spencer, E. Bern, F. Schiller, L. Vygotsky, A. Samoilenko, I. Hoffmann, W. Wundt, H.-G. Gadamer, D. Uznadze and many others. For the most part, all researchers agreed that play is one of the most common phenomena in human society and that it determines the processes that occur in human culture. In this regard, the main aim of this article is to consider the phenomenon of play as a necessary component of musical art, highlighting the importance of play logic in musical and stage genres. The research methodology is based on the combination of musicological, historical, psychological, philosophical, culturological approaches that create a single discursive field of our research.

\section{On the essence of a "play" phenomenon}

Much has already been said about the origin of the phenomenon of "play" and the role of the play principle in human activity, but we would like to highlight the opinion of J. Huizinga 
that "play is older than culture, because the concept of culture, no matter how unsatisfactory it would be described, in any case presupposes a human community, while animals did not wait at all for the appearance of man, so that he would teach them to play " (Huizinga J., 1997: 21). At the same time, the author notes that already in its simplest forms, play is something more than a simple physiological phenomenon or reaction. J. Huizinga points out that "play is a function that is full of meaning. At the same time, in the play there plays something that goes beyond the immediate striving to maintain life, something that brings sense to the action taking place", and further, "the purposefulness of the play brings to light a certain intangible element included in the very essence of the play" (Huizinga J., 1997: 21).

Consequently, without the phenomenon of play, just as without the manifestation of its elements, it is impossible to imagine the existence of a person. So, even Plato said that play is an integral component of both ancient culture and man himself, and also pointed out that the foundations of his ideal state are such components as play, which he understands as the basis of being, laws and people. In her work "Life as a stage play in the representation of the ancient Greeks", A.A. Takho-Godi examines in detail the views of ancient Greek philosophers on the fundamental principles of the structure of the human community, emphasizing at the same time that it is play in this that acquires special significance, influencing both the person himself and those socio-cultural processes that he initiates (Takho-Godi A., 1999).

H.-G. Gadamer wrote that "the play of art is more of a mirror that has been reappearing in front of us over the millennia. In it we see ourselves - often in a rather unexpected or alien form - as we are, as we can be, as we exist" (Gadamer H.-G., 2006: 168). The author further writes that the traditional division, which exists almost everywhere, in which there is a distinction between play and serious behavior, indicates a "lost freedom", since "the preached antagonism between life and art is part of the experience of an alienated world; it is an abstraction that obscures the interdependence of art and life, when the universality of the field of action and the ontological dignity of the play are not recognized" (Gadamer H.-G., 2006: 168). Consequently, a significant part of the research, in particular - the works of J. Huizinga, H.-G. Gadamer et al., present the play as a cultural universal, and see the source of a person's cultural activity in play, which can be compared with a generalized idea of the concept of the play genesis of culture. Play, in culture, as J. Huizinga points out in "Homo ludens", appears as "a given value" that precedes the culture itself, "accompanying and permeating it from its origins up to the phase of culture that the observer himself is experiencing at the moment" (Huizinga J., 1997: 23). In other words, the manifestations of play and its presence are found in almost everything that differs from the manifestations of an ordinary everyday character.

J. Huizinga notes that in the play, along with the psychological and physiological components, its aesthetic component is clearly manifested, since the play is simultaneously "redundant and self-interested" (A. Samoilenko, 2003); it must be strictly structured, capable of organizing the space around itself and be attractive, beautiful. In other words, the play should evoke bright, joyful, festive sensations. In addition to the above-mentioned characteristics, the play has a number of aesthetic components, which J. Huizinga himself calls, including balance and tension, variation and contrast, opening and resolution, as well as two of its key properties - rhythm and harmony - can be taken as a characteristic of an artistic, as well as musical form (Samoilenko A., 2003). The named characteristics can be correlated with the musical composition as its play component, since they actualize the basic rule of the play, which consists of creating a certain artistic convention and a new artificial order created thanks to it, replacing the real one and competing with it. J. Huizinga here also points out one more important property of the play - its ability to liberate, "reincarnate" and thus open up 
new resources of vital forces (Samoilenko A., 2003). Further, J. Huizinga defines the play as "an action that takes place within a certain framework of place, time and meaning, in a foreseeable order, according to voluntarily accepted rules and outside the sphere of material benefit or necessity" (Huizinga J., 1997: 44). This definition reveals the actional and communicative nature of the play, since, on the one hand, it can be the result of public communicative activity, and on the other, it can acquire the character of an illusory, fantasy communication with fictitious partners. The actional or activity component of the play is manifested in the modeling and demonstration of a life or imaginary situation. So, Y. Lotman defines the play as a "special type of model of reality", in which the realization of the behavior of the play type, "different from the practical one, and from the one determined by referring to the models of the cognitive type" is manifested (Lotman Y., 2002: 390). The researcher believes that play, as well as art, simulate reality in their own way, and also allow solving difficult life situations by applying a simpler system that allows each time to look at a specific problem in a new way, in other words, leave some place for fiction.

This art studies and culturological position in relation to the phenomenon of play differs significantly from the traditional psychological attitude, in which play is considered as a kind of role-playing manifestation of a person's personal beginning (principle), including the most negative and even destructive manifestations (Osadcha $S$. $V$., 2020). The aim of this kind of manifestation of play is short-term socio-psychological domination, which can at a certain moment, in a similar artificial way, significantly increase the positive self-esteem of a particular individual. However, such a play rather shows a certain dependence of human consciousness on social rules and established norms, which rather limit the creative and life possibilities of a person, as a result of which such a play is far from free and productive action.

So, discussing the problem of a play, A. Samoilenko comes to the conclusion that "while recognizing the target autonomy of the play process (playing disinterestedness, expediency without a goal, which after the Kantian theory of the aesthetic have become a common place in works of art studies), its productivity and outcome should be recognized as well - as a person's achievement of the highest ("summit", in L. Vygotsky's terminology) degree (and stage) of self-realization (self-actualization, in A. Maslow's terminology), that is, cognition and liberation of his essence, true existential purpose, familiarization with the higher semantic order" (Samoilenko A., 2003). A. Samoilenko suggests calling this approach to the phenomenon of play as noetic. According to the author, play, viewed as a noetic phenomenon, encourages the abandonment of all temporary gains for the sake of the main one - gaining oneself as a creative subject; art "teaches" such a play (A. Samoilenko, 2003).

In the work of M. Bakhtin "Creativity of Francois Rabelais and the folk culture of the Middle Ages and the Renaissance", play phenomena are considered on the basis of the analysis of laughter culture and carnivalization. The author points out that "the laughter principle and the carnival outlook underlying the grotesque destroy the limited seriousness and all claims to the timeless significance and unconditionality of ideas about necessity and free human consciousness, thought and imagination for new possibilities. That is why great upheavals, even in the field of science, are always preceded by the well-known carnivalization of consciousness that prepares them in advance" (Bakhtin M., 1990: 27). And it should be emphasized that the ideas of carnivalization and laughable outlook become harbingers of significant changes in the social and cultural spheres and are conductors of new ideas, which is especially important for us, since the position of M. Bakhtin largely explains the origins of the laughable, grotesque line in musical art. 


\section{Play and its specific artistic and image principles as a necessary component of musical art}

The specific play artistic attitudes of a composer or performer and their correlation with individual-style composer attitudes and performing style have already repeatedly become the subject of scientific study and comprehension. This issue is widely discussed in the works of M. Bakhtin, E. Nazaikinsky, A. Samoilenko, V. Klimenko, Y. Lotman, A. Lebedev, M. Maksimenko and others, on the pages of which the phenomenon of play reveals a direct functional relationship with various spheres of human activity (social, psychological, aesthetic, artistic, semantic, communicative). For our research, the works of E. Nazaikinsky V. Klimenko, A. Lebedev, M. Maksimenko, demonstrating the understanding of this phenomenon from the point of view of musical language, are of particular importance.

Thus, E. Nazaikinsky asserts that in a piece of music, play logic is completely subordinated to composition, and is embodied in intonation forms. The author points out that "almost all the found instrumental-play figures.... are limited to three perspectives corresponding to the triad "characteristic - emotional - logical": establishing the nature of the emerging syntactic element (its modus and intonation constants), clarifying its relationship to the previous elements and determining the way of appearance (smooth entry, sharp intrusion, juxtaposition)" (Nazaikinsky E., 1982: 226). E. Nazaikinsky sees the essence of musical logic in concertizing"musical play logic is the logic of concertizing, the logic of the collision of various instruments and orchestral troupes, various components of the musical fabric, different lines of behavior, which together form a "stereophonic" theatrical picture of a developing action, but more generalized and specific, than even in musical theater" (Nazaikinsky E., 1982: 226-227). It is in instrumental music that the possibility of a quick change of various artistic images arises, which, according to E. Nazaikinsky, owes this freedom from speech, "from singing with the text, from submission to extended lines of monologue speech" (Nazaikinsky E., 1982: 226-227).

The problem of play, play logic is directly related to the phenomenon and manifestations of theatricality in musical art. At the junction of different types of arts, the study and various discussions of this issue have repeatedly arisen. One of the first works affecting this subject area were the works of N. N. Evreinov, Russian and French director, playwright, historian, theoretician and theater reformer, an active participant in the cultural life of the first decades of the XX century. In a series of works ("Theater as such" (1912) and "Theater for oneself" (1915-1917)), the author substantiates the meaning and place of the play element in people's lives and touches on the problem of "theatricality", while the final formation of the concept of "theatricality" and "theatricalization" is described by him in two works: "Introduction to monodrama" (1909) and "Apology of theatricality" (1913). Talking about theatricality, N. Evreinov means "an aesthetic monstration of an obviously tendentious nature, which, even far from the theater building, with one delightful gesture, one beautifully intoned word creates a stage, scenery and frees us from the shackles of reality - easily, joyfully and without fail" (Evreinov N., 2002: 40-41).

N. Evreinov also touches on the problem of audience perception ("Apology of theatricality"), pointing out the conventionality of theatrical art, where the reality artificially created on the stage does not mislead anyone, since "an agreement is silently concluded between the artist and the viewer at the moment of aesthetic perception ... by virtue of which the viewer commits to such, and not a different attitude to aesthetic visibility, but the artist commits to maintain fully armed such an attitude" (Evreinov N., 2002: 40). N. Evreinov proposes a new, expanded interpretation of the concept of "theatricality", presenting it as "the instinct of transformation, the instinct of opposing images taken from outside, images arbitrarily created by a person" (Evreinov N., 2002: 43). In his opinion, theatricality goes beyond the theatrical stage 
and fills the entire society, and in this understanding, it becomes "an all-encompassing principle of being" (Dzhurova T., 2010: 19).

Musical play logic becomes the object of research by A. Lebedev, who focuses his attention on the characteristics of this definition, which the author interprets as the interaction of the composer's thinking with performing understanding and interpretation. The author points out that "the play logic in music took shape in the process of the formation of intonational thinking and therefore is primarily associated not with the play itself, but with the reflection of play activity and play thinking. Play in music is manifested as a reflection of play life situations (A. Lebedev, 2006: 20-21). The researcher defines play as a communicative activity that is a product of thinking and the result of emotional reactions. M. Maksimenko, studying the problems of play logic in the composer's work of the XX century, sees the identification of the author's initiative and creative strategy as the main vectors of the problem being studied; performing interpretation of the composer's idea and audience interactivity (Maksimenko M., 2011). Of course, we are mainly talking about the research methods of the composers of the second half of the XX century, but in many ways the research algorithm proposed by the author is also relevant for studying the work of composers of other time layers.

$\mathrm{V}$. Klimenko in his dissertation work formulates the concept of "extrapolation of general play principles into the field of musical art" (V. Klimenko, 1999). The author defines the types of play structures, among which he names: the play structure of "competition" (the principle of competition), the play structure of the "mosaic" (the principle of combinatorics) and the play structure of "mystification" (the principle of ambivalence) with the definition of the action of the above-mentioned structures on the abstract logical; philosophical and aesthetic; musical and style, compositional; musical and stylistic levels and in the field of interpretation ( V. Klimenko, 1999: 5-6). Explaining the meaning of these levels, V. Klimenko points out that the presence of the play structure of "competition" creates a special integrity, in which the ambivalence of elements is not accentuated, but a search for new ways of understanding and synthesizing traditions arises, for which the principle of "competitiveness" turns out to be very productive; the play structure of the "mosaic" reveals a tendency towards a combination of stable and mobile elements in conditions of preservation of "a certain initial group of elements" (V. Klimenko, 1999: 5-6); the play structure of the "mystification" demonstrates "balancing on the verge of the obvious and the hidden" - in this case, the leading tendency becomes the transformation of text elements into indexes of signs, which can be recognized only by the one who owns the information and therefore is able to decipher it.

\section{Conclusions}

Creative individuality in the process of an artistic act realizes in its activity antinomic attitudes of the phenomenon of play, which can be designated as "conditional - unconditional (conventional - non-conventional, artificial, illusory - "true", real)" (A. Samoilenko, 2003: 104), revealing and thereby emphasizing that artistic impact (composing and performing activities), as well as artistic perception (interpretation of a specific composition or listening perception) equally need knowledge and adherence to artistic rules and compositional boundaries. Hence are the play purpose and various play functions of the composition (form of work) in music.

The key principle here is the play principle, which is expressed in the dialogical play comparisons of a musical composition, in the special principles of musical and linguistic expression, as well as in tempo-rhythmic and agonic relations. The continuity of the pulse of "sounding" and "non-sounding" time helps the performer (and composer) to master the irreversible element of "living time", which musical art reveals even in the most abstract moments - it is always connected with real processes, with action, or even just with movement. 
Consequently, the triad of the concepts of play - composition - motor ability, forms a single conceptual field, which contributes to the identification of the features of the ways of formation of music. Moreover, in this triad, it is the third component - motor ability - that appears as the first manifestation of the play purpose of the artistic form, which in turn is a manifestation of the inner drama and psychological subtext of the composition, which correlates it with stage and theatrical action, the phenomenon of theatricality, which acquires special relevance in musical art in general, and opera forms in particular.

\section{References}

Bahtin, M. (1990) Tvorchestvo Fransua Rable i narodnaya kultura Srednevekovya i Renessansa. [Creativity of Francois Rabelais and folk culture of the Middle Ages and the Renaissance]. Moscow: Hudozhestvennaya literature. [in Russian].

Dzhurova, T. (2010) Koncepciya teatralnosti v tvorchestve N.N. Evreinova. [The concept of theatricality in the work of N.N. Evreinova]. Saint Petersburg: Sankt-Peterburgskaya akademiya teatralnogo iskusstva. [in Russian].

Evreinov, N. (2002) Demon teatralnosti. [Demon of theatricality]. Moscow-Saint Petersburg.: Letnij sad. [in Russian].

Gadamer, H.-G. (2006) Igra iskusstva. Voprosy filosofii. [Game of art. Philosophy questions]. Moscow. [in Russian].

Huizinga, J. (1997) Homo Ludens. "Chelovek igrayushij»: Stati po istorii kultury [Homo Ludens. "Man playing»: Articles on the history of culture]. Moscow: Progress-Tradiciya. [in Russian].

Klymenko, V. (1999) Ihrovi struktury v muzytsi: estetyka, typolohiia, khudozhnia praktyka. [Game structures in music: aesthetics, typology, artistic practice]. Kyiv. [in Ukrainian].

Lebedev, A. (2006) Muzykalnaya igrovaya logika v zhanre koncerta dlya bayana s orkestrom:

problemy kompozicii i ispolnitelskoj interpretacii. [Musical game logic in the genre of a concert for button accordion and orchestra: problems of composition and performance interpretation]. Saratov. [in Russian].

Lotman, Yu. (2002). Stati po semiotike kultury i iskusstva. [Articles on the semiotics of culture and art]. Saint Petersburg: Akademicheskij Proekt. [in Russian].

Maksimenko, M. (2011) Igrova logika v muzichnomu mistectvi XX stolittya: do pitannya pro strategichnist kompozitorskogo mislennya. Aktualni problemi istoriyi, teoriyi ta praktiki hudozhnoyi kulturi [Game logic in the musical art of the twentieth century: to the question of the strategic nature of composer's thinking. Current issues of history, theory and practice of art culture]. Vol. 26. Kyiv: Milenium [in Ukrainian].

Nazajkinskij, E. (1982) Logika muzykalnoj kompozicii [The logic of musical composition]. Moscow: Muzyka. [in Russian].

Osadcha, S. (2020) Theoretical aspects of studying the symbolic foundations of liturgical and singing tradition. Musicological discourse and problems of contemporary semiology: collective monograph. Lviv-Toruń: Liha-Pres. [in English].

Samoilenko, A. (2003) Dialog kak muzykalno-kulturologicheskij fenomen: metodologicheskie aspekty sovremennogo muzykoznaniya. [Dialogue as a musical and cultural phenomenon: methodological aspects of modern musicology]. Kyiv. [in Russian].

Taho-Godi, A. (1999) Zhizn kak scenicheskaya igra v predstavlenii drevnih grekov. Grecheskaya kultura $v$ mifah, simvolah i terminah [Life as a stage play in the mind of the ancient Greeks. Greek culture in myths, symbols and terms]. Saint Petersburg: Aletejya [in Russian]. 